\title{
International Trademark Law: A Pathfinder and Selected Bibliography
}

\author{
by Minde Glenn Browning*
}

\section{INTRODUCTION}

A trademark is any "word, slogan, design, picture, or any other symbol used to identify and distinguish goods." These symbols are used by businesses and consumers in the marketplace. Consumers associate trademarks with the quality of a product (either low or high) and use this information to identify desired goods, distinguish competing products, and make informed decisions regarding merchandise. ${ }^{2}$ Businesses rely on trademarks to establish their reputation, distinguish competitor's products, advertise, and market goods. ${ }^{3}$

A trademark is a creative endeavor and is considered intellectual property with protectable rights. ${ }^{4}$ In the United States, trademarks are protected by state common law, federal and state statutes, and by

* Assistant Director for Readers' Services, Law Library, Indiana University School of Law-Indianapolis; B.A., Western Michigan University; M.L.S., Indiana University; J.D., 1994, Indiana University School of Law-Indianapolis.

1. J. Thomas McCarthy, McCarthy's Desk Encyclopedia of Intellectual Property 339 (1991). In the United States, trademark protection also includes service marks, certification marks and collective marks. Service marks identify and distinguish services. Certification marks are marks used by persons other than their owners to certify regional or other origin, material, mode of manufacture, quality, accuracy, or other characteristics of goods or services, or that the work or labor on goods or services was performed by members of a union or other organization. Collective marks are trademarks or service marks used by members of a cooperative, an association, or ' other collective group or organization, and include marks indicating membership in a union, association, or other organization. United States Trademark (Lanham) Act, 15 U.S.C. $\$ 1127$ (1988 \& Supp. IV 1992). Service marks, certification marks and collective marks may not be recognized or registerable in foreign jurisdictions. The term "trademark" as used in this article includes any trademark, service mark, collective mark or certification mark.

2. J. Thomas McGarthy, McCarthy on Trademarks and Unfair Competition, $\$ 2.01(2)$ (3d ed. 1992) [hereinafter McCarthy].

3. McCarthy's Desk Encyglopedia of Intellectual Property, supra note 1 , at 340 .

4. Id. at 166 . 
federal and state registrations. As businesses expand beyond national borders, trademarks help to efficiently open markets and gain consumer recognition of products or services. Because protection is based on the laws of each individual country, the scope of trademark protection is geographically limited. ${ }^{5}$ Foreign trademarks are usually procured by filing applications in national trademark offices with the help of foreign associates. ${ }^{6}$ Several international systems simplifying administrative procedures are in place through international agreements, although they create neither a worldwide trademark system nor a worldwide trademark.

International trademark systems are evolving to meet new multinational economic challenges. The latest worldwide developments in trademark law are found in new multinational treaties. ${ }^{7}$ These new treaties are dramatic steps forward in creating a uniform system despite the difficulties that have been encountered in developing multinational agreements thus far.

\section{Literature on Treaties, Conventions, Agreements}

\section{A. Multilateral Agreements}

\section{Paris Convention for the Protection of Industrial Property}

The Paris Convention for the Protection of Industrial Property (Paris Convention) is the principal international treaty protecting intellectual property rights, including patents and copyrights as well as trademarks. $^{8}$ The Paris Convention has been revised at Brussels, Washington, The Hague, London, Lisbon, and Stockholm. ${ }^{9}$ The United

5. "Under the territoriality doctrine, a trademark is recognized as having a separate existence in each sovereign territory in which it is registered or legally recognized as a mark." McCARTHY, supra note $2, \$ 29.01(1)$.

6. Jerome Gilson, 1a Trademark Protection and Practice $\$ 9.05$ (1993) [hereinafter Gilson].

7. John B. Pegram, Europe, Trademarks and 1992, 72 J. Pat. [\& Trademark] OfF. Soc'y 1060 (1990)[hereinafter Pegram].

8. Paris Convention for the Protection of Industrial Property, July 7, 1884, Reprinted in Marshall Leaffer, International Treaties on Intellectual Property 17 (1990); 3 Digest of Commercial Laws of the World, Digest of Intellectual Property Laws (1990); Gilson, supra note 6, App. 9a.

9. Revised at Brussels on Dec. 14, 1900, 32 Stat. 1936, T.I.A.S. No. 411, 1 Bevans 296; Washington revision of 1911, 37 Stat. 1645, T.I.A.S. No. 579, 204 Official Gazette 1011, July 21, 1914; The Hague revisions of 1925, 47 Stat. 1789, T.I.A.S. No. 834, 2 Bevans 524, 407 Official Gazette 23, June 9, 1931; London revision of 1934,53 Stat. 1748, T.I.A.S. No. 941, 2 Bevans 223, 613 Official 
States became a signatory to this international treaty in $1887 .{ }^{10}$

The Paris Convention establishes that member countries provide national protection to trademark owners from other countries who apply for trademark protection, and that member countries afford intellectual property a minimum level of protection. " The Paris Convention also established the organizational structure for administering the treaty, including an International Bureau, which is the Secretariat for the Treaty ${ }^{12}$ and the Paris Union (the group name for the member countries). ${ }^{13}$ The International Bureau was incorporated into the World Intellectual Property Organization (WIPO) when WIPO took over administration of the Paris and Madrid Unions. ${ }^{14}$

As a member of the Paris Union, the United States is bound by the principle of territoriality: a trademark has a separate existence in each sovereign territory in which it is registered or legally recognized as a mark. ${ }^{15}$ Paris Union trademark owners must therefore obtain national protection through the laws of each Paris Union country in which they intend to do business. United States trademark law provides equivalent protection for Paris Union trademark owners and United States citizens. ${ }^{16}$

Gazetre 23, August 3, 1948; Lisbon revision of 1958, 53 Stat. 1748, 13 U.S.T. 1, T.I.A.S. No. 4931, 775 Official GazetTe 321, February 13, 1962; Stockholm revision of 1967, 21 U.S.T. 1583, T.I.A.S. No. 6923, 852 Official Gazette 511, July 16, 1968.

10. 33 Indus. Prop. 10 (1994). A revised list of treaty participants is published in the first yearly issue of Industrial Property. Additional changes are published throughout the year.

11. McCarthy, supra note 2 , at $\$ 29.10(1)$. See also Gilson, supra note $6, \$$ 9.07. In addition, the Paris Convention established a nationally-based priority filing date. Foreign trademark registration applications filed within twelve months of the national application retain the filing priority of the date of the home country trademark registration application. Id.

12. Paris Convention, supra note 8. See, e.g., Article 13 (Assembly of the Union), Article 14 (Executive Committee), Article 15 (International Bureau), and Article 16 (Finances).

13. Id. Article 1 (Establishment of the Union).

14. Convention Establishing the World Intellectual Property Organization, July 14, 1967, 21 U.S.T. 1749, reprinted in LEAFFER, supra note 8, at 563. See infra Part V.A. of this Article.

15. MCCARTHY, supra note $2, \$ 29.01(1)$.

16. The mechanism of United States protection of foreign trademarks is outlined in McCarthy, supra note 2, 20.04 . 


\section{Selected Bibiography on the Paris Convention}

Convention of the Union of Paris for the Protection of Industrial Property, 48 Trademark ReP. 1320 (1958) (Including the revisions adopted at Lisbon).

L.A. Ellwood, Industrial Property Convention and the "Telle Quelle" Clause, 46 Trademark Rep. 36 (1956).

Stephen P. Ladas, The Lisbon Conference for Revision of the International Convention for the Protection of Industrial Property, 48 Trademark Rep. 1291 (1958).

Allan Zelnick, Shaking the Lemon Tree: Use and the Paris Union Treaty, 67 Trademark ReP. 329 (1977).

\section{The Madrid Agreement Concerning the International Registration of} Marks of 1891

Under the Paris Convention, trademark owners must obtain separate trademark protection in each Paris Union country. The Paris Convention does not provide trademark protection across Paris Union members' borders. Foreign trademark registration was made easier through an international trademark system established by The Madrid Agreement Concerning the International Registration of Marks of 1891 (Madrid Agreement). ${ }^{17}$ Although it is a separate agreement, the Madrid Agreement flows from the Paris Convention. Therefore, countries wishing to participate in the Madrid Agreement must be members of the Paris Union. ${ }^{18}$ The United States is not a signatory to the Madrid Agreement. ${ }^{19}$

The Madrid Agreement extends the Paris Convention's territoriality principal through a centralized registration filing system that ultimately results in individual national registrations in Madrid Agreement member countries (Madrid Union). Through a trademark owner's home country trademark office, the owner of a trademark registration may file a single international registration application that designates some or all of the individual countries within the Madrid Union. This single

17. The Madrid Agreement Concerning the International Registration of Marks, Apr. 14, 1891, 828 U.N.T.S. 389; reprinted in LEAFFER, supra note 8, at 229; Text of Act of Nice, Madrid Agreement, Ratified December 15, 1964, 55 Trademark ReP. 758 (1965).

The system established in 1891 is relatively unchanged despite revisions at Brussels in 1900, at Washington in 1911, at the Hague in 1925, at London in 1934, at Nice in 1957 and at Stockholm in 1967. Arpad Bogsch, The First Hundred Years of the Madrid Agreement Concerning the International Registration of Marks, 30 Indus. Prop. 389 (1991).

18. Rudolf Gallmann, Callmann on Unfair Competition, Trademarks and Monopolies $\$ 26.03$ (4th ed. 1981).

19. 33 Indus. Prop. 12 (1994). 
application is then forwarded to WIPO, which publishes the mark in the international register Les Marques Internationales and forwards the registration to the trademark offices of the designated countries. The trademark offices of the designated countries then determine the validity of each WIPO registration under the trademark laws of the designated countries. The single Madrid Agreement application therefore culminates in a series of national registrations unless national registration is denied by the trademark office of any designated country. ${ }^{20}$

Many aspects of the Madrid Agreement have prevented United States adherence to this treaty. United States objections primarily regard the central attack feature (a dependency provision), ${ }^{21}$ the lack of trademark use provisions, ${ }^{22}$ the requirement of a national registration as a basis for the WIPO international application (instead of a national application only), and the short length of time allowed to examine international applications. ${ }^{23}$ Other United States concerns include dif-

20. Gilson, supra note $6, \$ 9.02(2)$; Callmann, supra note $18, \$ 26.03$. See also Stephen P. Ladas, 2 Patents, Trademarks and Related Rights: National and International Protection 758-795 (1975)(Providing extensive detail). Although there are consistent references to a WIPO "international registration," it is neither international nor a registration. The WIPO system merely provides a single point to apply for individual national trademark registrations and no legal effect is given to the WIPO registration unless and until the individual foreign national trademark offices recognize the trademark as valid under national laws. International Trademark Association, Madrid Protocol: A Practitioner's Guide (1993).

21. Central attack permits a third party to cancel or amend the WIPO registration and all national registrations obtained therethrough, via an attack on the home trademark owners' national registration. Since the WIPO registration is dependent on an effective home registration, a successful third party attack on the home registration cancels or amends the WIPO registration as well. This provision may result in the invalidation of national trademark registrations which are based on the WIPO registration even in countries where the third party has no trademark rights. David Tatham, 'Central Attack' and the Madrid Agreement, 4 Eur. Intell. Prop. Rev. 91 (1985). Also, United States law provides grounds for attacking United States trademark registrations not recognized in other countries, thus rendering United States trademark owners more vulnerable under the Madrid Agreement than are other Madrid Union members. Gilson, supra note $6, \$ 9.07(2)$.

22. To obtain United States trademark protection, a trademark must be used in commerce that Congress may regulate, e.g., interstate commerce. Roger E. Schechter, Facilitating Trademark Registration Abroad: The Implication of U.S. Ratification of the Madrid Protocol. 25 Geo. Wash. J. Int'l L. \& Econ. 419, 421 (1991). See also McCarthy, supra note $2, \& 16$.

23. Given the length of time generally required for a United States trademark registration application to become a registration, United States trademark owners are disadvantaged because the basis for the WIPO international application registration is 
ferences over the breadth of goods and services descriptions in trademark registrations, increases in the numbers of registrations, and the increasing number of abandoned trademark registrations creating deadwood on a national register. ${ }^{24}$

The arguments surrounding United States non-adherence to the Madrid Agreement are nicely laid out as point, counter point, and rejoinder by Robert J. Patch in The Arrangement of Madrid for the International Registration of Trademarks, 50 J.P.O.S. 603 (1968). The issue of adherence to the Madrid Agreement was the source of extensive debate in the United States trademark community in the $1960 \mathrm{~s} .{ }^{25}$ While the United States trademark community did not advocate adherence to the Madrid Agreement, there was general support for developing a workable international trademark registration system. ${ }^{26}$

\section{Selected Bibliography on the Madrid Agreement}

Gabriel M. Frayne, A Few More Thoughts on Possible United States Adherence to the Madrid Arrangement, 57 Trademark Rep. 477 (1967).

Andrew R. Klein, Report on the Conference on International Trademark Problems (Held on May 19, 1965 at the Department of Commerce), 55 TrAdeMARK REP. 752 (1965).

Madrid Agreement, 55 Trademark Rep. 758 (1965).

Robert J. Patch, The Arrangement of Madrid for the International Registration of Trademarks, 50 J.P.O.S. 603 (1968).

a home national registration. United States businesses could file a trademark application directly with foreign offices and obtain more timely and better trademark protection. Similarly, the time for refusing an international application is too short for the lengthy examination process required by United States trademark law. GiLson, supra note 6, 9.02(2).

24. Stephen P. Ladas, 2 Patents, Trademarks and Related Rights: National and International Protection $\$ 761$ (1975). See also Gabriel M. Frayne, History and Analysis of TRT, 63 TRADEMARK REP. 422, 423 (1973) (Proliferation of trademark applications, deadwood on the national register, national registration as the basis of international registration application, and limitations on the number of classes in filing); Schechter, supra note 22 (National registration as basis for filing, central attack; administrative burdens for the United States Trademark Office, working language French, deadwood on the national register).

25. LADAs, supra note $24, \$ 795$. This debate came about as a result of a Commerce Department conference on international trademark problems. See Andrew R. Klein, Report on the Conference on International Trademark Problems (Held on May 19, 1965 at the Department of Commerce), 55 Trademark ReP. 752 (1965). In 1967, Stephen P. Ladas advocated that the United States propose a new agreement rather than adopt the Madrid Agreement and attempt to amend either United States law or the Agreement itself. See Ladas, Proposal for a New Agreement for International Registration of Trademarks, 57 Trademark Rep. 433 (1967).

26. Anthony R. DeSimone, In Support of TRT, 63 Trademark Rep. 492 (1973). 
Special Issue: Should the United States Adhere to the Madrid Agreement?, 56 Trademark ReP. 289 (1966):

The Position For Adherence:

David B. Allen, A Report on the Madrid Agreement 289;

Anthony R. DeSimone, United States Adherence to the Agreement of Madrid, 320;

Edward G. Fenwick, United State Participation-Madrid Agreement, 323;

Gerald D. O'Brien, The Madrid Agreement Adherence Question, 326 ;

Norman St. Landau, Some Comments on Possible Adherence to the Madrid Agreement, 337.

The Position Against Adherence:

Stephen P. Ladas, The Madrid Agreement for the International Registration of Trademarks and the United States, 346 \& Additional Memorandum 361;

Eric D. Offner, The Madrid Agreement and Trends in International Trademark Protection 368.

David Tatham, Central Attack and the Madrid Agreement, 7 Eur. Intell. Prop. Rev. 91 (1985).

\section{Trademark Registration Treaty}

Striving for better participation in an international trademark registration system, WIPO held a conference in 1971. ${ }^{27}$ Madrid Union members in attendance did not want to make radical amendments to the Madrid Agreement; therefore a new treaty, the Trademark Registration Treaty (TRT), ${ }^{28}$ was developed. ${ }^{29}$

27. See, e.g., Madrid Arrangement-BIRPI Proposed Changes, 60 Trademark Rep. 129 (1970); Eric D. Offner, A New Proposal for the International Registration of Trademarks, 61 Trademark Rep. 8 (1971); Jeremiah D. McAuliffe, Prospects for Improved Protection of Trademarks in International Trade, 61 Trademark REP. 82 (1971); Gabriel M. Frayne, Report on the International Registration of Trademarks-Revision of the Madrid Arrangement, 61 Trademark Rep. 95 (1971).

28. Trademark Registration Treaty, (TRT) Vienna, June 12, 1973, 63 Trademark ReP. 640 (1973), Reprinted in LeafFer, supra note 8, at 293; Draft Trademark Registration Treaty, 902 Official Gazette U.S. Pat. \& Trademark Off. TM105 (Sept $19,1972)$.

29. Gabriel M. Frayne, History and Analysis of TRT, 63 Trademark ReP. 422, 423 (1973). 
The TRT was the first attempt to develop an international system for all Paris Union members, including the United States. The TRT was a filing treaty designed to reduce the complexity of registration application filing and of administering trademark registrations. It was not designed to change substantive trademark law. The TRT did not create a true multinational registration, but did provide for direct filing with WIPO. ${ }^{30}$ The TRT also required a three year suspension of the trademark use requirement, which would have substantively affected United States trademark law. ${ }^{31}$

The TRT went to a diplomatic conference in Vienna on May 12, 1973. It was signed by the United States on June $12,1973,{ }^{32}$ but inherent conflicts with United States trademark law prevented ratification despite proposed amending legislation. ${ }^{33}$ The TRT is considered a failure since it was only ratified by the five Paris Union countries which brought the treaty into force. ${ }^{34}$

\section{Selected Bibliography on the Trademark Registration Treaty}

David B. Allen, The Trademark Registration Treaty: Its Implementing Legislation, 21 IDEA 161 (1980).

D.C. Maday, A European Perspective on the Proposed New Trademark Registration Treaty, 62 Trademark ReP. 353 (1972).

Beverly W. Pattishall, Proposed Trademark Registration Treaty and Its Domestic Import, 62 Trademark Rep. 125 (1972).

Beverly W. Pattishall, Use Rationale and the Trademark Registration Treaty, 61 A.B.A. J. 83 (1975).

Symposium, The Trademark Registration Treaty (TRT), Vienna June 12, 1973, 63 TRademark ReP. 421 (1973):

30. Callmann, supra note $18, \$ 26.04$. A detailed discussion of all aspects of the TRT is found in Stephen P. Ladas, 3 Patents, Trademarks and Related Rights: National and International Protection 95 804-827 (1975).

31. McCarthy, supta note $2, \$ 29.10(3)$.

32. Callman, supra note $18, \$ 26.04$.

33. Trademark Registration Treaty Implementing Legislation, 973 Official Gazette U.S. Pat. \& Trademark Off. T.M.O.G. 3 (Aug. 1, 1978)(Summary of TRT and proposed legislative changes in the Lanham Act).

34. Arpad Bogsch, The First Hundred Years of the Madrid Agreement Concerning the International Registration of Marks, 30 Indus. Prop. 389, 406 (1991). The five countries which ratified the TRT were Burkina Faso, Congo, Gabon, the Soviet Union, and Togo. 30 Indus. Prop. 15 (1991). Although the January issue of Indus. Prop. contains listings of the various intellectual property treaty participants, the TRT has not been listed since 1991 . 
Gabriel M. Frayne, History and Analysis of TRT, 422;

Canadian Joint Committee Report-AIPPI and The Patent and Trademark Institute, 448;

Shigeru Otsuka, Where Will Japan Go with the TRT?, 465;

The Association of Swedish Patent Agents-Position on TRT, 471; William E. Schuyler, TRT, A Chance to Modernize Our Trademark Statute, 478;

Anthony R. DeSimone, In Support of TRT, 492;

Robert C. Cudek, TRT Impact on United States Statutory and Common Law, 501;

Walter J. Derenberg, The Myth of the Proposed International Trademark "Registration" Treaty (TRT), 531;

Stephen P. Ladas, What Does the Vienna Trademark Registration Treaty Mean to the United States?, 551;

Eric D. Offner, TRT-A Lemon Tree?, 563, 569;

William Page Montgomery and Roger A. Reed, Constitutionality Report on Proposed Trademark Registration Treaty, 575.

Trademark Registration Treaty: Clearing the Path to International Protection, 6 LAW \& POL'y INT'L Bus. 1133 (1974).

7. Protocol Relating to the Madrid Agreement Concerning the International Registration of Marks

After the failure of the Trademark Registration Treaty, WIPO began work on yet another registration treaty ${ }^{35}$ by establishing The Committee of Experts on the Registration of Marks. ${ }^{36}$ The Committee developed a draft Trademark Cooperation Treaty, ${ }^{37}$ but eventually abandoned the planned development of an entirely new treaty system, instead advocating improvements in existing treaties for worldwide trademark administration. ${ }^{38}$ Even though the Madrid Agreement pro-

35. Gerd F. Kunze, The Protocol Relating to the Madrid Agreement Concerning the International Registration of Marks of June 27, 1989, 82 TRADEMARK REP. 58 (1992).

36. Paris Union, Committee of Experts on the International Registration of Marks, First Session (Geneva, February 11 to 14, 1985), 24 Indus. Prop. 165 (1985); Paris Union, Committee of Experts on the International Registration of Marks, Second Session (Geneva, December 11 to 13, 1985), 25 Indus. Prop. 56 (1986); Paris Union, Committee of Experts on the International Registration of Marks, Third Session (Geneva, November 11 to 14, 1986), 26 Indus. Prop. 56 (1986).

37. Detailed Outline of a Proposed New Treaty on the International Registration of Trademarks, 25 Indus. Prop. 92 (1986).

38. Paris Union, Committee of Experts on the International Registration of Marks, Third Session (Geneva, November 11 to 14, 1986), 26 Indus. Prop. 56 (1986). 
vides a cost effective and convenient multinational trademark system, increased membership and participation was desired by WIPO. For example, four European Community countries (Denmark, Greece, Ireland, and the United Kingdom) are not Madrid Union members, nor are other countries such as Japan and the United States. It also seemed important to the Committee of Experts to establish a cross-over between the Madrid Agreement and the Community Trade Mark then being developed by the European Community. ${ }^{39}$ To accomplish these objectives, WIPO initially developed two Protocols for the Madrid Agreement, but the two were collapsed into a single Protocol that provides for an international trademark registry for individual member nations and for intergovernmental organizations. ${ }^{40}$

The Protocol Relating to the Madrid Agreement Concerning the International Registration of Marks ${ }^{41}$ (Madrid Protocol) ${ }^{42}$ was adopted by the Diplomatic Conference for the Conclusion of a Protocol Relating to the Madrid Agreement Concerning the International Registration of Marks in June $1989,{ }^{43}$ but is not yet in force. ${ }^{44}$ The Protocol is similar to the Madrid Agreement, but includes significant changes that give it more universal appeal..$^{45}$ The Madrid Protocol differs from the Madrid Agreement in four major areas: 1) the international application is based on either an issued national registration or a registration

39. Gerd F. Kunze, The Protocol Relating to the Madrid Agreement Concerning the International Registration of Marks of June 27, 1989, 82 TRADEMARK REP. 58, 62 (1992).

40. Diplomatic Conference for the Conclusion of a Protocol Relating to the Madrid Agreement Concerning the International Registration of Marks (Madrid, June 12 to 28, 1989), 28 INDUs. Prop. 253 (1989).

41. Protocol Relating to the Madrid Agreement Concerning the International Registration of Marks, 28 Indus. Prop. 253, 254 (1989); reprinted in Leaffer, supra note 8, at 251.

42. Sometimes referred to as Madrid II.

43. Diplomatic Conference for the Conclusion of a Protocol Relating to the Madrid Agreement Concerning the International Registration of Marks (Madrid, June 12 to 28, 1989), 28 INDus. Prop. 253 (1989).

44. Under Article 14, the Protocol requires four instruments of ratification, one of which must be in a Madrid Agreement country and another in a non-Madrid Agreement country. As of December 1993, there were 27 signatory states: Austria, Belgium, Democratic People's Republic of Korea, Denmark, Egypt, Finland, France, Germany, Greece, Hungary, Ireland, Italy, Liechstenstein, Luxembourg, Monaco, Mongolia, Morocco, Netherlands, Portugal, Romania, Russian Federation, Senegal, Spain, Sweden, Switzerland, United Kingdom, and Yugoslavia. Spain is the only country that has ratified the treaty. 33 Indus. Prop. 20 (1994).

45. Gilson, supra note $6,9.07(3)$. 
application; 2) national trademark offices are given a longer time period for issuing a refusal notification; 3 ) the fee structure is revised; and 4) the effects of central attack are diminished because an attacked international WIPO registration can nevertheless be converted into separate national registrations. ${ }^{46}$

These changes seemed to address the major objections to the Madrid Agreement. ${ }^{47}$ However, there are still some concerns about United States adherence, namely: the administrative burdens on the United States Trademark Office (both in the increased number of applications and the time limits for refusing an international application); the disadvantages arising from the difficulty in obtaining a United States registration vis-a-vis registrations in countries with either less stringent or no effective examination; the fact that central attack can be used more effectively against United States trademark owners; and the increased deadwood on the national registers will result in an increase in opposition and cancellation proceedings. ${ }^{48}$

If the Madrid Protocol is adopted, trademark owners in the United States will be able to reduce the time, efforts, and costs of obtaining multiple foreign trademark registrations. ${ }^{49}$ However, these cost benefits will not be realized if United States trademark owners encounter objections in foreign national offices. ${ }^{50}$

The Madrid Agreement and the Madrid Protocol will operate simultaneously and independently, ${ }^{51}$ although organizationally there will

46. Id. 9.07(3). See also Ian Jay Kaufman, The Madrid Protocol: Should the U.S. Join?, N.Y. L.J., 5 (October 9, 1992), (Describing the differences between the Agreement and the Protocol); Pegram, supra note 7, at 1060 (Describing the four distinctions). Cf. Kunze, supra note 35 , at 62 . However, this change in the central attack provision may not be an improvement. If the cancelled registrations are pursued for the purpose of converting them to national trademark registrations independent of the WIPO registration, the third party (attacking) trademark owner must defend the trademark defeated through a central attack in other foreign venues.

47. Schechter, supra note 22 , at 433.

48. Norm J. Rich, Comment, United States Participation in the Madrid Protocol: What Is the Price of Admission?, 5 Temp. Int'L \& Comp. L.J. 93 (1991)(Actual Protocol regulations may require changes in United States trademark law; Protocol participants have varying filing requirements; determining filing date and priority); Ian Jay Kaufman, Madrid Protocol: Should the United States Be Swept up in the Rising Tide?, Trademark World, October 1991, 27 (1993).

49. Ian Jay Kaufman, Madrid Protocol: Should the United States Be Swept up in the Rising Tide?, Trademark World, 27 (1993).

50. Id.

51. Rich, supra note 48 . 
be one Union for both treaties. ${ }^{52}$ A safeguard clause governs the interaction of the two treaties and situations arising in countries with dual membership. ${ }^{53}$ Because of the parallel existence of the Madrid Agreement and Madrid Protocol, trademark owners and practitioners will face increased complexity in their businesses. Identifying a registerable trademark may be more difficult because of problems in interpreting search results due to the potential increases in the volume of registrations and applications. Registrations under national law, the Madrid Agreement, or the Madrid Protocol may each have different rights and procedures for renewal, cancellation, and assignment. ${ }^{54} \mathrm{De}$ tails of the planned Madrid Protocol processes are well explained by Gerd F. Kunze in The Protocol Relating to the Madrid Agreement Concerning the International Registration of Marks of June 27, 1989, 82 TRAdemaRK REP. 58 (1992). Draft regulations are now being developed..$^{55}$

In 1993, legislation entitled the Madrid Protocol Implementation Act was introduced in both the United States House of Representatives (H.R. 2129) ${ }^{56}$ and the United States Senate (S. 977). ${ }^{57}$ These bills will provide for the administrative procedures needed to file Madrid Protocol applications in the United States Patent and Trademark Office, ${ }^{58}$ and make it possible for the United States to become a member of the Madrid Protocol. The House Bill was highly endorsed at hearings that took place in May 1993. ${ }^{59}$ The opinions expressed in the literature both endorse adherence and advise a cautious approach. ${ }^{60}$

52. Kunze, supra note 35 .

53. Id. at 80 .

54. Ian Jay Kaufman, Protocol Impact on Trademark Office and Trademark Lawyers, N.Y. L.J. 5 (November 6, 1992).

55. Reprinted in 1991 Current Develoments in Trademark Law and Unfair Competition 57. For discussions of the provisions of the draft, see Madrid Union, Working Group on the Application of the Madrid Protocol of 1989, Fourth Session (Geneva November 11 to 18, 1991), 31 Indus. Prop. 62 (1992); Madrid Union, Working Group on the Application of the Madrid Protocol of 1989, Third Session (Madrid May 21 to June 17, 1991), 30 Indus. Prop. 280 (1991); Madrid Union, Working Group on the Application of the Madrid Protocol of 1989, Second Session (Geneva November 26 to 30, 1990), 31 Indus. Prop. 62 (1992).

56. 139 Cong. Rec. E1259 (May 17, 1993).

57. Id. at 6026 (May 18, 1993)(Including the text of the bill and extensive comments by Senator DeConcini in support of the bill).

58. Id. at 6027.

59. Although the hearings were not yet available at the time of this printing, a Clinton Administration representative announced their strong "support of U.S. accession to the Protocol." The International Trademark Association representative 


\section{Selected Bibliography on the Madrid Protocol}

International Trademark Association, Madrid Protocol: An Opportunity for United States Trademark Owners (1993).

International Trademark Association, Madrid Protocol: A Practitioner's Guide (1993).

Ian Jay Kaufman, Draft Regulations, Like Protocol, Lack Answers, 208 N.Y. L.J., 5 (November 13, 1992).

Ian Jay Kaufman, How the Madrid Agreement Differs from the Protocol, 208 N.Y. L.J., 5 (October 23, 1992).

Ian Jay Kaufman, Madrid Protocol: Should the United States Be Swept up in the Rising Tide?, Trademark World 27 (1993).

Ian Jay Kaufman; The Madrid Protocol: Should the U.S. Join?, 208 N.Y. L.J., 5 (October 9, 1992).

Ian Jay Kaufman, The Madrid Protocol: Step Toward "Harmonization," 208 N.Y. L.J., 5 (October 16, 1992).

Ian Jay Kaufman, Modifications, Application Can Further Backlog Agency, 208 N.Y. L.J., 5 (October 30, 1992).

Ian Jay Kaufman, Protocol Impact on Trademark Office and Trademark Lawyers, 208 N.Y. L.J., 5 (November 6, 1992).

Ian Jay Kaufman, Treaties and Trademarks, 19 INT'L Bus. LAw. 531 (1991).

Gerd F. Kunze, The Protocol Relating to the Madrid Agreement Concerning the International Registration of Marks of June 27, 1989, 82 Trademark REP. 58 (1992).

Norm J. Rich, Comment, United States Participation in the Madrid Protocol: What Is the Price of Admission?, 5 Temp. InT'L \& Comp. L.J. 93 (1991).

announced support with reservations. Jeffery M. Samuels and Linda B. Samuels, The U.S. Position on the Madrid Protocol, 13 Eur. Intell. Prop. Rev. 418, 420 (1993).

60. See, e.g., Ian Jay Kaufman, Draft Regulations, Like Protocol, Lack Answers, N.Y. L.J. 5 (November 13, 1992)(United States should not join until the implications of the problems have been demonstrated or addressed); Allan Zelnick, The Madrid Protocol-Some Reflections, 82 Trademark Rep. 651 (1992)(Madrid Protocol will be counterproductive to United States trademark owners unless United States trademark law is substantively changed); Schechter, supra note 22 (Facilitates commercial expansion, speedy adherence is advised). 
Jeffery M. Samuels and Linda B. Samuels, The US Position on the Madrid Protocol, 13 Eur. Intell. Prop. Rev. 418 (1993).

Roger E. Schechter, Facilitating Trademark Registration Abroad: The Implication of U.S. Ratification of the Madrid Protocol, 25 Geo. Wash. J. INT'L L. \& ECON. 419 (1991).

\section{New Developments}

With an expected proliferation in the volume of international trademark registration applications, WIPO continues its work toward simplified trademark registrations procedures. ${ }^{61}$ The latest WIPO initiative is the Treaty on the Simplification of Administrative Procedures Concerning Marks (Trademark Law Treaty), ${ }^{62}$ which is designed to address the present complexities of trademark administration. The Trademark Law Treaty will streamline processes by regulating the elements comprising a trademark registration and the filing procedures for registration applications, renewals, and assignments. ${ }^{63}$ It also regulates electronic communication between national trademark offices, establishes minimum filing requirements, and requires standardized forms, a single application for multiple class trademarks, and a general power of attorney (not a separate power of attorney for each member country). The treaty avoids procedural issues such as oppositions or substantive examination, and is not an attempt to harmonize trademark law worldwide. ${ }^{64}$ The treaty is expected to be adopted by the Diplomatic Conference for the Conclusion of the Trademark Law Treaty which is scheduled to meet from October 10 to 28, 1994 in Geneva, Switzerland. ${ }^{65}$

\section{B. Trademark Treaties on Limited Topics \\ 1. Geographic Indications}

Geographic names utilized as trademarks have been the subject of international controversy, and two treaties were developed to deal with

61. Arpad Bogsch, Trademarks in 2017: Their Creation and Protection, 82 Trademark REP. 880 (1992).

62. Treaty on the Simplification of Administrative Procedures Concerning Marks or the Trademark Law Treaty, 32 Indus. PROP. 180 (1993)(Meeting of five consultants to review draft treaty and draft regulations); Draft Trademark Law Treaty, 32 INDUs. Prop. 339, 340 (1993); Draft Regulations Under the Trademark Law Treaty, 32 Indus. Prop. 339, 340 (1993).

63. Gilson, supra note $6, \$ 9.03$.

64. Richard J. Taylor, Proposed Treaty Would Streamline International Trademark Procedure, 15 Nat'L L.J., 13 (May 17, 1993).

65. 33 Indus. Prop. 61 (1994). 
this issue. There are two types of geographic indication of origin. First, a trademark may indicate that the product originates in a referenced geographic location. Second, the trademark may be an appellation of origin that indicates that the product possesses certain qualities, characteristics or features associated with a geographic place. ${ }^{66}$

a. The Madrid Agreement for the Repression of False or Deceptive Indications of Origin

The Madrid Agreement for the Repression of False or Deceptive Indications of Origin $^{67}$ requires seizure of imported goods falsely indicating geographic origin. Through this treaty, geographic names in trademarks were given substantive protection until the 1958 revisions to the Paris Convention incorporated the false indications of origin. ${ }^{68}$ The United States is not a member. ${ }^{69}$

b. The Lisbon Arrangement for the Protection of Appellations of Origin and Their International Registration

The Lisbon Arrangement for the Protection of Appellations of Origin and Their International Registration ${ }^{70}$ provides absolute protection for registered geographic denominations. A geographic name cannot be used as a trademark if it is protected in the country of origin. ${ }^{11}$ The United States is not a member. ${ }^{72}$

\section{c. Selected Bibliography on Geographic Indications}

Lee Bendekgey and Caroline H. Mead, International Protection of Appellations of Origin and Other Geographic Indications, 82 TrademarK ReP. 765 (1992).

66. Lee Bendekgey and Caroline H. Mead, International Protection of Appellations of Origin and Other Geographic Indications, 82 Trademark ReP. 765 (1992).

67. Reprinted in Leaffer, supta note 8, at 270. See also International Convention: Arrangement of Madrid for the Prevention of False or Misleading Indications of Origin as Amended at Lisbon on October 31, 1958, 57 Pat. \& Trademark Rev. 225 (1959).

68. McCarthy, supra note $2, \$ 29.10(5)(a)$. See also LADAs, supra note 24 , 847. Cf. Bendekgey, supra note 63 (Paris Convention does not apply to geographic indications that are likely to mislead).

69. 33 Indus. Prop: 11 (1994).

70. Reprinted in LeafFer, supra note 8, at 278.

71. McCarthy, supra note 2, $\$ 29.10(4)$. See also Ladas, supra note $24, \$ 861$.

72. 33 Indus. Prop. 16 (1994). 
M.G. Coerper, The Protection of Geographical Indications in the United States of America, with Particular Reference to Certification Marks, 29 Indus. Prop. 232 (1990).

J. Thomas McCarthy and Veronica Colby Devitt, Protection of Geographical Demoninations: Domestic and International, 69 Trademark ReP. 199 (1979).

Lori E. Simon, Appellations of Origin: The Continuing Controversy, $5 \mathrm{Nw}$. J. INT'L L. \& Bus. 132 (1983).

L. Sordelli, The Future Possibilites of International Protection for Geographical Indications, 30 Indus. Prop. 154 (1991).

\section{Classification Treaties}

Trademark registrations require a description of the goods and services to be protected by the registration. The national laws of many countries vary in the particularity of their description requirements. In an environment where trademarks are being registered internationally, uniformity in description requirements is desirable because it facilitates filing of registration applications and eliminates questions regarding infringement or confusion.

a. The Nice Agreement on the International Classification of Goods and Services for the Purposes of the Registration of Marks

The International Classification system was developed by the International Bureau to facilitate the trademark searching process and the international description of goods and services covered by trademark registrations. The classification system of the International Bureau was adopted in June $1957^{73}$ as The Nice Agreement on the International Classification of Goods and Services for the Purposes of the Registration of Marks. ${ }^{74}$ The classifications are changed and revised by a Committee of Experts. ${ }^{75}$ The United States became a signatory to this treaty in $1972 .{ }^{76}$

73. LADAs, supra note $24, \$ 800$.

74. Reprinted in LEAFFER, supra note 8, at 499.

75. In December 1992, the Preparatory Working Group of the Committee of Experts of the Nice Union met and approved classification changes and considered a proposal to restructure certain classes. Nice Union: Preparatory Working Group of the Committee of Experts, Twelfth Session (Geneva, November 2 to 6, 1992), 32 Indus. Prop. 109 (1993).

76. 33 Indus. Prop. 15 (1994). 
The Nice Agreement requires that each trademark published or registered indicate the International Classification. However, there is no requirement that the classification system become the principle national trademark classification scheme. ${ }^{77}$

b. The Vienna Agreement Establishing an International Classification of the Figurative Elements of Marks

The Vienna Agreement Establishing an International Classification of the Figurative Elements of $\mathrm{Marks}^{78}$ covers designs or figurative elements of trademarks. Twenty-nine classes of figurative elements (e.g. Human Beings, Animals, Plants, Landscapes, and Geometric Figures.) were developed in the draft. As in the goods and services classification system, adopting countries do not have to adopt the same figurative classifications as the national scheme, but figurative registrations must include the classification information. ${ }^{79}$ The United States is not a member of this treaty. ${ }^{80}$

\section{c. Selected Bibliography on Classification Treaties}

Stephen P. Ladas, Patents, Trademarks and Related Rights: National and International Protection (1975) \$\$ 800-802 (Nice Agreement on the International Classification of Goods and Services); $\$ 803$ (Vienna Agreement on the International Classification of Figurative Elements).

Jessie N. Marshall, Classification of Services Under the International (Nice) Agreement, 82 Trademark ReP. 94 (1992).

Daniel L. Skoler, Trademark Identification-Much Ado About Something?, 76 Trademark Rep. 224 (1986).

\section{Regional and Other Limited Agreements}

1. Types of Regional Agreements

Other treaties have been entered into by numerous countries or by more limited groups of countries. These agreements have a limited scope which may or may not impact United States trademark owners. These treaties fall into two categories: those providing for a single

77. LADAS, supra note $24, \$ 801$.

78. Reprinted in LEAFFER, supra note 8 , at 546.

79. LADAS, supra note $24, \$ 803$.

80. 33 Indus. Prop. 15 (1994). 
registration for a group of countries (a true multinational trademark) ${ }^{81}$ and those which create some economic integration or harmonization among countries. ${ }^{82}$ An example of a single registration treaty is the Benelux Treaty providing for one registration for Belgium, the Netherlands, and Luxembourg.

Harmonization treaties include the Pan American Convention of $1929^{83}$ and the Andean Pact Convention. ${ }^{84}$ The Pan American Convention of $1929^{85}$ consists of two separate parts: A Convention for Trade Mark and Commercial Protection, and a Protocol on Inter-American Registration of Trade Marks. The United States is a member of the Pan American Convention, but renounced the Protocol in the mid1940s. The Bureau administering the treaty has closed. ${ }^{86}$ The Pan American Convention is one of three Inter-American Conventions that are still in effect to some degree. The Convention's parties are only bound by the latest agreement signed. ${ }^{87}$ These Conventions have little significance in view of the Paris Convention. ${ }^{88}$

Trademark rights can also be internationally protected through bilateral agreements between individual countries. The United States has agreements of this nature with China, Ethopia, the German Democratic Republic, Greece, Ireland, Italy and Japan. ${ }^{89}$ For an historical listing of individual treaties see P. Federico, Treaties Between the U.S.

81. Frayne, supra note 29 , at 423.

82. William H. Ball, Attitudes of Developing Countries to Trademarks, 74 Trademark REP. 160, 169 (1984).

83. Pan American Convention of 1929. Inter-American Convention for the Protection of Trade-marks, signed at Washington February 20, 1929; ratified by the President of the United States February 11, 1931; ratification of the United States deposited with the Pan American Union February 17, 1931; proclaimed February 17, 1931. Convention and protocol effective as to the United States February 17, 1931. 46 Stat. 2907; T.S. No. 833; IV Treaties (Trenwith) 4768; 380 Official Gazette U.S. Pat. \& Trademark Off. 245.

84. Reprinted in 3 Dig. of Com. Laws of the World, Dig. of Intell. Prop. Laws (L. F. Quevedo trans., 1990).

85. Pan American Convention of 1929 , supra note 83 .

86. Gilson, supra note $6, \$ 9.08$.

87. McCarthy, supra note 2, 29.10(2) (1929, 46 Stat. 2907: Columbia, Cuba, Guatemala, Haiti, Honduras, Nicaragua, Panama, Paraguay, Peru and the United States)(1923, 44 Star. 2494: Brazil, Dominican Republic)(1910, 39 Stat. 1675: Ecuador and Uruguay).

88. McCarTHY, supra note $2, \$ 29.10(2)$.

89. Id. (China, 63 Stat. 1299 (1948); Ethopia, 4 U.S.T. 2134 (1953); German Democratic Republic, T.I.A.S. No. 3593 (1956); Greece, 5 U.S.T. 1829 (1954); Ireland, 1 U.S.T. 550 (1950); Italy, 63 SraT. 2255 (1949); Japan, 4 U.S.T. 2063 (1953)). 
and Other Countries Relating to Trade-Marks, 39 Trademark Rep. 1 (1949) (Supp.).

2. Selected Bibliography on Regional and Other Limited Agreements

a. Andean Pact

Stephen P. Ladas, Latin American Economic Integration and Industrial Property, 62 Trademark Rep. 1 (1972).

Jerimiah D. McAuliffe, Reacting to Trademark Developments in Latin America, 65 Trademark Rep. 503 (1975).

Peter Schliesser, Restrictions on Foreign Investment in the Andean Common Market, 5 INT'L LAW. 586 (1972).

Antonio R. Zamora, Andean Common Market-Regulation of Foreign Investments: Blueprint for the Future?, 10 INT'L LAW. 153 (1976).

\section{b. Benelux}

Richard Ebbink, 'Other Use' of Trade Marks: A Comparison Between U.S. and Benelux Trade Mark Law, 14 Eur. Intell. Prơp. Rev, 200 (1992).

C. Gielen, Better Protection of Service Marks in the Benelux??, 8 Eur. Intell. Prop. Rev. 79 (1986).

Eric D. Offner, Benelux Trademark Convention, 54 Trademark ReP. 102 (1964).

Dirk Pieter Raeymaekers, Assignments, Licenses and Abandonment of Trademarks in the Benelux, 68 Trademark Rep. 15 (1978).

Jan T. Van't Hoff, Benelux Treaty and Uniform Law on Trademarks-a General Description , 60 Trademark ReP. 595 (1970).

\section{c. Pan American Treaties}

Walter J. Halliday, Inter-American Conventions for Protection of Trade-Marks, 32 J.P.O.S. 661 (1950).

Stephen P. Ladas, Pan American Conventions on Industrial Property, 22 Ам. J. INT'L L. 803 (1928).

Jeremiah D. McAuliffe, Consideration of Inter-American Conventions, 52 Trademark ReP. 25 (1962). 


\section{Trademark Provisions in Non-Intellectual Property Treaties \\ 1. Examples of Non-Intellectual Property Treaties}

Other multilateral treaties have provisions covering trademarks and other intellectual property. The Uruguay Round of the General Agreement on Tariffs and Trade ${ }^{90}$ (GATT) includes trademark and other intellectual property issues. The GATT intellectual property provisions are also known as The Agreement on Trade-Related Aspects of Intellectual Property Rights, Including Trade in Counterfeit Goods or TRIPS. Trademark protection through GATT is desirable because developing countries resist following the Paris Convention, and GATT offers an established, enforceable system of trade protection. ${ }^{91}$ The North American Free Trade Agreement (NAFTA) ${ }^{92}$ is one of the latest examples of this type of trade agreement. TRIPs and NAFTA both establish minimum standards of protection for intellectual property and retain the principle of territoriality. ${ }^{93}$

The European Community was established by several treaties with the intent of removing geographic barriers between European countries. The principal EC intellectual property law developments have included an erosion of the independence of national trademark rights when in conflict with EC treaty provisions, as well as restrictions on a trademark owner's ability to prevent imports of its own goods legitimately using the trademark in another member county (also known as "gray market goods') ${ }^{94}$

The EC is actively developing laws to eliminate trademark barriers: a draft regulation has proposed a new Community Trade Mark System (CTM), and a directive on the harmonization of national trademark laws was adopted in December 1988. ${ }^{95}$ The CTM provides trademark owners with a single trademark enforceable in all EC countries, but

90. TRIPs (Annex III), Draft Final Aict Embodying The Results of The Uruguay Round of Multilateral Trade Negotiations, MTN.TNC/W/FA, 20 Dec. 1991, GATT Secretariat UR-91-0185.

91. R. Michael Gadbaw and Timothy J. Richards, Intellectual Property Rights in the New GaTT Round, Intellectual Property Rights: Global Consensus, Global Conflict?, (1988).

92. Article 1708: Trademarks. 1 North American Free Trade Agreement Between the Government of the United States of America, the Government of Canada and the Government of the United Mexican States 17-5 (1993).

93. Gilson, supra note $6, \$ 9.10$.

94. Pegram, supra note 7, at 1060.

95. Gilson, supra note $6,9.09$. 
does not override already-established national trademark rights. ${ }^{96}$ The development (and adoption) of the Madrid Protocol may have an impact on EC trademark law because Article 14 of the Protocol allows regional organizations to become members of the Protocol. ${ }^{97}$

\section{Selected Bibliography on Non-Intellectual Property Treaties}

a. North American Free Trade Agreement (NAFTA)

Daniel R. Bereskin, Comparison of the Trademark Provisions of NAFTA and TRIPs, 83 Trademark Rep. 1 (1993).

b. General Agreement on Tariffs and Trade (GATT)

Daniel R. Bereskin, Comparison of the Trademark Provisions of NAFTA and TRIPs, 83 Trademark ReP. 1 (1993).

Peter Crockford, GATT Considerations, 8 Trademark World 24 (1993).

D. Peter Harvey, Efforts Under GATT, WIPO and Other Multinational Organizations Against Trademark Counterfeiting, 15 Eur. Intell. Prop. Rev. 446 (1993).

Eleanor K. Meltzer, TRIPs and Trademarks, or GATT Got Your Tongue?, 83 Trademark ReP. 18 (1993).

\section{c. European Community}

The trademark in the European Community has generated a large volume of literature. Below is a selected bibliography of recent articles.

European Community Harmonization: Common Denominator-Now or Ever?, Trademark World 26 (1993).

Michael Fawlk, Trademark Delimitation Agreements Under Article 85 of The Treaty of Rome, 82 Trademark ReP. 223 (1992).

Charles Gielen, Harmonization of Trade Mark Law in Europe: The First Trade Mark Harmonization Directive of the European Council, 14 Eur. INTELL. Prop. Rev. 262 (1992).

96. Id.

97. J. Rosini and C. Roche, Trademarks in Europe 1992 and Beyond, 13 Eur. Intell. Prop. Rev. 404, 408 (1991). The Madrid Protocol may eliminate the need for a separate CTM, but also would allow many other nations access to a CTM. 
Richard Jenkins, To Examine or Not to Examine for Prior Rights in the Community Trademark Office, Trademark World (1993).

Thomas Ardel Larkin, Harmony in Disarray: The European Community Trademark System, 82 Trademark Rep. 634 (1992).

Doris E. Long,. Survey of Recent Development in Trademark Law in the European Communities, 18 INT'L LAW. 163 (1984).

Dinah Nissen and Ian Karet, The Trademarks Directive: Can I Prevail if the State Has Failed?, 15 Eur. Intell. Prop. Rev. 222 (1990).

John B. Pegram, Europe, Trademarks and 1992, J. Pat. [\& Trademark] OFF. Soc'Y 1060 (1990).

John Richards, Recent Developments Concerning Trademark and the European Economic Community, 74 Trademark ReP. 146 (1984).

Adrian Y. Spencer, European Harmony: Confusion or Conflict, Trademark WORLD 23 (1993).

David C. Wilkinson, The Community Trade Mark Regulation and Its Role in European Economic Integration, 80 Trademark REP. 107 (1990).

\section{Conducting Additional Research in International Trademark LaW}

\section{A. Research Aids}

\section{General Works on Trademark Treaties}

The International Encyclopedia of Comparative Law ${ }^{98}$ provides a general overview of the entire spectrum of intellectual property treaties. Of special note are section 76 on the international registration of trademarks, section 77 regarding indications of source and appellations of origin, and section 82 covering European trademark law developments. Basic information on trademark treaties and developments in international trademark law can be also be found in the major trademark treatises, although coverage varies. J. McCarthy, McCarthy on Trademarks and Unfair Competition, (3d ed. 1993) ${ }^{99}$ and J. Gilson, Trademark Protection and Practice (1993) ${ }^{100}$ provide overviews of the philosophies and general principals of the treaties. $R$.

98. 14 The International Encyclopedia of Comparative Law Ch. 1 (Copyright and Industrial property; General Questions-The International Conventions).

99. Section 29.10 covers International Trademark treaties.

100. Chapter 9 covers Foreign Trademark Protection. 
Callmann, Callmann on Unfair Competition, Trademarks and Monopolies (4th ed. 1981), ${ }^{101}$ and S. Ladas, Patents, Trademarks and Related Rights: National and International Protection (1975) have more detailed information on trademark treaty provisions and working mechanisms.

Interesting historical accounts of treaty development are included in the discussion of the multilateral trademark treaties in conjunction with the European Community treaties and trademark directives by J. Pegram in Europe, Trademarks and 1992, J. Pat. [\& Trademark] Off. Soc'y 1060 (1990). Developments leading up to the Madrid Agreement are recounted by A. Bogsch in The First Hundred Years of the Madrid Agreement Concerning the International Registration of Marks, 30 Indus. Prop. 389 (1991). Gerd F. Kunze traces trademark treaty evolution from the Madrid Agreement to the Madrid Protocol in The Protocol Relating to the Madrid Agreement Concerning the International Registration of Marks of June 27, 1989, 82 Trademark ReP. 58 (1992)

\section{General Works on International Trademark Law and Practice}

International trademark law is dependent on the laws of the individual countries. Sources for the trademark laws of individual countries include Digest of Commercial Laws of the World, Digest of Intellegtual Property Laws (1990); and Trademarks Throughout the World (1979). In McCarthy on Trademarks and Unfair ComPETITION (3d ed. 1992), the author covers the process of United States protection of foreign trademarks and many other aspects of international trademark law. International competition law is generally detailed by Callmann in Gallmann on Unfair Competition, Trademarks and Monopolies $\ 27$ (1981).

\section{B. Databases}

There are two types of trademark databases, those containing the actual registered trademarks (on national and international registers) and those containing information about trademark issues. National register search strategies and databases are detailed by $\mathrm{N}$. Thompson in Intellectual Property Materials Online/CD-ROM; What and Where, 15 Database 14 (1992). Registry databases are international in scope although the most readily available to United States researchers are

101. Section 26 focuses on International Trademark conventions and the intricacies of international protection. 
primarily North American and European. The database reviews focus on British and United States services. CD-ROM resources are databaselike because the access through machine search can be superior to book indexing. The United States Patent and Trademark Office materials on CD-ROM are also reviewed.

Mathew Bender \& Co., Inc. publishes all of its intellectual property treatises on one CD-ROM entitled SEARCH MASTER. This service provides better indexing than most book sources, but access is limited to publications for which subscriptions exist.

WIPO has made pertinent data from the Madrid Agreement international register available on ROMARIN CD-ROM (Read-OnlyMemory of the Madrid Actualized Registry INformation). ${ }^{102}$

Information about trademark issues is available on both LEXIS and WESTLAW. LEXIS compiles trademark material in the TRDMRK library (Trademark and Unfair Competition Law Library), which primarily covers United States national trademark information. International aspects are pulled in through publications with an international scope such as Trademark Reporter, BNA's Patent, and Trademark Copyright LAW DaILY. The LEXIS TRDMRK Library also includes customs administration rulings and ITC decisions, as well as the text of intellectual property treaties. The ITRADE (International Trade Law Library) and EURCOM (European Community) libraries may also include items of interest, but their broader coverage will bring in extraneous materials.

WESTLAW provides information primarily in the topical databases labeled with the prefix FIP. The Practicing Law Institute (PLI) course handbooks are a unique source with practical information and reprints of some primary source material. The WESTLAW gateway to DIALOG provides access to national registry databases such as TRADEMARKSCAN (produced by Thompson \& Thompson) which contains United States trademark registrations and applications for registration.

\section{Periodicals}

Trademark Reporter, 5 , New York: International Trademark Association, 1911-present.

European Intellectual Property Review, Oxford, Oxfordshire: ESC Publications, Ltd., 1978-present. 
Industrial Property: Monthly Review of the World Intellectual Property Organization, Geneva: WIPO, 1961. present.

IIC: International Review of Industrial Property and Copyright LaW. Munich, West Germany: Max Planck Institute for Foreign and International Patent, Copyright and Competition Law, 1969-present.

World Intellectual Property Report, London: BNA International, 1988-present.

Trademark World, London: Intellectual Property Pub., 1986present.

IV. Selected Bibliography on Specific Issues in International Trademark LaW

\section{A. Counterfeiting}

J. Joseph Bainton, Reflections on the Trademark Counterfeiting Act of 1984: Score a Few for the Good Guys, 82 Trademark ReP. I (1992).

J. Joseph Bainton, Seizure Orders: An Innovative Judicial Response to the Realities of Trademark Counterfeiting, 73 TrademaRK REP. 459 (1983).

James A. Carney, Setting Sights on Trademark Piracy: The Need for Greater Protection Against Imitation of Foreign Trademarks, 81 TRADEMARK REP. 30 (1991).

Donald Knox Duvall, Unfair Competition and the ITG: Actions Before the International Trade Commission Under Section 337 of THE TARIFF Act of 1930 (1993).

D. Peter Harvey, Efforts Under GATT, WIPO and Other Multinational Organizations Against Trademark Counterfeiting, 15 Eur. Intell. Prop. Rev. 446 (1993).

Edward Kania, International Trademark and Copyright Protection, 8 LoY. L.A. INT'L \& Comp. L.J. 721 (1986).

Perla M. Kuhn, Remedies Available at Customs for Infringement of a Registered Trademark, 70 Trademark ReP. 387 (1980).

Clark W. Lacker, International Efforts Against Trademark Counterfeiting, 1988 Colum. Bus. L. Rev. 161 (1988). 
Elizabeth J. Lintini, Note, Commercial Trademark Counterfeiting in the United States, the Third World and Beyond: American and International Attempts to Stem the Tide, 8 B.C. Third World L.J. (1985).

Diane E. Preblude, Note, Countering International Trade in Counterfeit Goods, 12 ВRоoк. J. INT' L. 339 (1986).

William N. Walker, A Program to Combat International Commercial Counterfeiting, 70 Trademark REP. 117 (1980).

\section{B. Developing Nations}

William H. Ball, Attitudes of Developing Countries to Trademarks, 74 TradeMARK REP. 160 (1984).

W.R. Cornish and Jennifer Phillis, The Economic Function of Trade Marks: An Analysis with Special Reference to Developing Countries, 13 I.I.C. 41 (1982).

Louis M. Gibson, The New Game-Trademark Handicapping, 69 TRADEMARK REP. 74 (1969).

Eva Csiszar Goldman, Note, International Trademark Licensing Agreements: $A$ Key to Future Technological Development, 16 CAL. W. INT'L L.J. 178 (1986).

Raymer McQuiston, Developing Countries Are Undermining Corporate America's Capacity to Market Its Creativity: $A$ Call for a Reasoned Solution by the United States Government in Light of the Continuing Deterioration of the International Trademark System, 14 Syracuse J. INT'L L. \& Com. 237 (1987).

Peter F. O'Brien, The International Trademark System and the Developing Countries, 19 IDEA 89, 93 (1978).

John P. Spitals, The UNCTAD Report on the Role of Trademarks, 11 N.Y. L. Sch. J. INT'L \& Comp. L. 369 (1981).

United Nations Conference on Trade and Development, The Role of Trademarks in Developing Countries, U.N. Doc TD/B/C.6/Ac.3/ 3/Rev. 1 (1979).

\section{Gray Market Goods/Parallel Imports}

Scott R. Bough, Note, The Seven Billion Dollar Gray Market: Trademark Infringement or Honest Competition?, 18 PAC. L.J. 261 (1986).

Baila H. Caledonia, Trademarks in the European Communities from an American Perspective, 18 Brook. J. OF INT'L. L. 751 (1993). 
Brian D. Coggio et al., The History and Present Status of Gray Goods, 75 Trademark Rep. 433 (1985).

E. John Krumholtz, The United States Customs Service's Approach to the Gray Market: Does It Infringe on the Purposes of Trademark Protection?, $8 \mathrm{~J}$. Comp. Bus. \& Cap. Market L. 101 (1985).

Seth E. Lipner, The Legal and Economic Aspects of Gray Market Goods (1990).

Pierrette Alyssa Newman, The United States Customs Service's Regulation of Gray Market Imports: Does It Preserve the Broad Protections Afforded by Section 516 of the Tariff Act of 1930?, 5 Dick. J. INT'L L. 293 (1987).

Linda S. Paine-Powell, Parallel Imports of Materially Different Grey Goods: Obtaining Customs Blockage or an Injunction, 15 Eur. Intell. Prop. Rev 122 (1993).

N. David Palmeter, Gray Market Imports: No Black and White Answer, 22 Trade 89 (1988).

J. Thomas Warlick IV, Comment, Of Blue Light Specials and Gray Market Goods: The Perpetuation of the Parallel Importation Controversy, 39 ЕмORY L.J. 347 (1990).

John A. Young, Jr., Note, The Gray Market Case: Trademark Rights $v$. Consumer Interests, 61 Notre Dame L. Rev. 838 (1986).

D. Harmonization

Charles Gielen, Harmonization of Trade Mark Law in Europe: The First Trade Mark Harmonization Directive of the European Council, 14 Eur. INTELl. Prop. Rev. 262 (1992).

Brian J. Letten and Gerd Kunze, Harmonization (Uniform Systems). Making History: Trademarks in 2017, 82 Trademark ReP. 912 (1992).

Allan S. Pilson and Peter Siemensen, Centralization (Uniform Systems). Making History: Trademarks in 2017, 82 TRAdemark ReP. 919 (1992).

\section{E. Licensing}

Robert Goldscheider, Eckstron's Licensing in Foreign and Domestic Operations: The Forms and Substance of Licensing. (1978). International Trademark Licensing Agreements: A Key to Future Technological Development, 16 CAL. W. INT'L L.J. 178 (1986).

R. Joliet, Trademark Licensing Agreements Under the EEC Law of Competition, 5 Nw. J. INT'L L. \& Bus. 755 (1983-84). 
H. Kinkeldey, Pitfalls of Trademark Licensing in the EEC, 72 Trademark REP. 145 (1982).

\section{F. Miscellaneous}

Thomas J. Hoffman \& Susan E. Brownstone, Protection of Trademark Rights Acquired by International Reputation Without Use or Registration, 71 Trademark ReP. 1 (1981).

Joseph M. Lightman, Protection of Generic Words Against Trademark Registration Abroad, 54 Trademark Rep. 80 (1964).

Jeremiah D. McAullife, Dilution Concept in International Trade, 61 TradeMARK REP. 76 (1971).

Virginia R. Richard, Management of Foreign Trademark Litigation, 7 Сом. \& L. 3 (1985).

\section{G. Uniform Trademark Laws}

Friedrich-Karl Beier and Arnold Reimer, Preparatory Study for the Establishment of a Uniform International Trademark Definition, 45 Trademark REP. 1266 (1955).

Hugo Mock, Is an International Trade-Mark Law Desirable Now?, 40 TrADEMARK REP. 3 (1950).

Edward D. Rogers \& Stephen P. Ladas, Proposals for Uniform Trademark Laws, 61 Trademark ReP. 8 (1950).

\section{InTERnational Organizations}

A. World Intellectual Property Organization (WIPO)

Established by a multinational treaty in $1967,{ }^{103}$ WIPO is the international body charged with promoting worldwide intellectual property protection through cooperative efforts and by coordinating the activities of the International Unions (Paris, Madrid, etc.). ${ }^{104}$ The secretariat, or governing body, was originally known as the International Bureau (BIRPI). ${ }^{105}$ When WIPO became a United Nations agency in

103. Convention Establishing the World Intellectual Property Organization, July 14, 1967, 21 U.S.T. 1749, Reprinted in LEAFFER, supra note 8, at 563.

104. Id. art. 3

105. United International Bureau for the Protection of Intellectual Property, or Bureaux Internationaux Internaux Reunis pour la Protection de la Propriete Intellectuelle. 
$1974, g^{106}$ the International Bureau became a part of the overall structure. ${ }^{107}$

There are two groups within the committee structure of particular interest to the area of international trademark law. The Permanent Committee on Industrial Property Information ad hoc Working Group on Trademark Information (PCIPI/TI) was established to explore various aspects of trademark information collection and storage. The working group surveyed trademark search systems, examination methods and application numbering systems. It is also in the process of developing a definition of a figurative trademark. ${ }^{108}$ The Committee of Experts on the Harmonization of Laws for the Protection of Marks is developing a trademark administration treaty to facilitate worldwide trademark filing. ${ }^{109}$

\section{B. Selected Bibliography on the World Intellectual Property Organization}

Eugene M. Braderman, The World Intellectual Property Organization and the Administrative Reorganization, 12 IDEA 673 (1968).

Harry Goldsmith, WIPO: A Noble Idea Whose Time Has Come, 12 IDEA 691 (1968).

Stephen P. Ladas, Patents, Trademarks and Related Rights: National and International Protection $\$ S$ 92-100 (1975).

\section{Other Organizations and Associations}

As part of the WIPO entry, the Yearbook of International Organizations provides a long list of related associations and organizations. Below is a sampling:

American Bar Association

Patent, Trademark \& Copyright Section (PTC Section)

750 N. Lake Shore Dr.

Chicago, IL 60611

American Intellectual Property Law Association (AIPLA)

106. Callmann, supra note $18, \$ 26.01$.

107. See supra note 103 , art. 9.

108. First Session reported at 31 Indus. Prop. 218 (1992), Second Session 32 Indus. Prop. 133 (1993), Third Session held October 1993. See supra Part II.A.5 of this Article for further discussion of this treaty.

109. See First Session, 29 Indus. Prop. 101 (1990); Second Session, 29 Indus. Prop. 375 (1990); Third Session, 31 Indus. Prop. 244 (1992); Fourth Session, 32 Indus. Prop. 89 (1993); Fifth Session, 32 Indus. Prop. 289 (1993); Sixth Session, 32 Indus. Prop. 339 (1993). See supra Part II.A.5 of this Article for further discussion of this treaty. 
2001 Jefferson Davis Hwy., Suite 203

Arlington, VA 22202

European Communities Trademark Association (ECTA)

SG Florence Gevers

c/o Bureau Gevers NV

Buekenlaan 12

B-2020, Antwerpen

Belgium

Inter-American Association of Industrial Property (ASIPI)

Maipu 1300

1006 Buenos Aires

Argentina

International Anti-Counterfeiting Coalition (IACC)

818 Connecticut Ave. N.W., Suite 1200

Washington, D.C. 20006

International Association for the Protection of Industrial Property (AIPPA)

Bleicherweg 58

CH-8029 Zurich

Switzerland

International Intellectual Property Association (IIPA) ${ }^{1 \text { i0 }}$

1255 23rd St. NW, Suite 850

Washington, D.C. 20037

International Trademark Association (INTA) ${ }^{11}$

1133 Avenue of the Americas

New York, NY 10036-6710

Licensing Executives Society International (LES)

71 East Ave., Suite 5

Norwalk, CT 06851

\section{Conclusion}

From the Paris Union to the Madrid Protocol and beyond, international trademark law continues to evolve. ${ }^{112}$ From a seemingly

110. Formerly the International Patent and Trademark Association.

111. Formerly the United States Trademark Association (USTA).

112. A timeline of important trademark developments is found in Preserving History, 82 Trademark ReP. 1021 (1992). 
immovable position in the mid-Twentieth century, the Madrid Protocol has been realized. However, some problems, such as centralization, trademark systems, and harmonization, which were identified then ${ }^{113}$ are still problems today.

In 1992 at Cannes, France, the International Trademark Association ${ }^{14}$ held a symposium entitled Making History: Trademarks in $2017,1^{115}$ to discuss the evolution of trademarks in the next 25 years. The issues identified at that symposium for the next 25 years include harmonization, centralization, enforcement and dispute resolution, confusion, trademark registration filing systems, and counterfeiting.

113. David B. Allen, Protection of Product Identity Abroad: Some New Light on an Old Problem?, 55 Trademark Rep. 707, 715 (1965) (Multiplicity of jurisdictions results in high protection costs; the disparity of use requirements causes confusion and inequities.).

114. See supra note 111 and accompanying text.

115. Symposium, Making History: Trademarks in 2017, 82 Trademark Rep. 829 (1992). 
